\title{
Martin Amis's The Pregnant Widow as a Postmodern Confessional Novel
}

\begin{abstract}
In this article I read Martin Amis's The Pregnant Widow as a confessional novel in relation to the profound postmodern skepticism about the language of truthfulness and format constrains of consummated confession. In addition to the contemporary discourse about confessional writing, I apply Jacques Derrida's idea of restructuring of personal memory traces and Mikhail Bakhtin's idea of confession with a loophole. I argue that in his autobiographical and self-reflexive novel Amis addresses his fictional doubles in wish to make sense of his personal traumatic experience and doubts multiple narrative and analytical frames directed towards closure and consummation of the Self.
\end{abstract}

\section{Keywords}

Martin Amis, The Pregnant Widow, postmodern confessional novel, traumatic experience, lack of consummation

[...] And just as there are no words for the surface, that is, No words to say what it really is, that it is not

Superficial but a visible core, then there is

No way out of the problem of pathos vs. experience.

You will stay on, restive, serene in

Your gesture which is neither embrace nor warning

But which holds something of both in pure

Affirmation that doesn't affirm anything [...]. - John Ashbery, Self-Portrait in a Convex Mirror

There's an "I" in the first sentence. The narrator is me but he disappears halfway through the book. 
It has been almost half a century since the publication of a sustained study by Peter M. Axthelm, The Modern Confessional Novel, defined a major impulse behind 'modern' confession from Dostoevsky onwards as the need and hope for "sincere, constructive confession", "a clearly perceived sense of self" (1967: 176). And, indeed, a capacity for suffering in a search for self-perception rather than purgation is what proves to be the central purpose of the modern confessional hero in the novels of Gide, Sartre, Camus, Koestler, Golding and Bellow.

Though Axthelm's study proposed a whole set of illuminating ideas for interpreting confessional novel genre poetics (e.g. principles of temporal manipulations and events selection, the functions of mirror symbols, the role of doubles, the irony of the author's detachment from his hero, etc.), the very cornerstones of confession - subjectivity, truth, authority, and representation - were systematically put into question by the next generation of postmodern confessional novelists. One of the crucial postmodern ideas about confession is doubt about the very possibility of confession via words. The traumatic experience as well as the confessant self are considered to be elusive and non-referential. Talking about "unconfessed confessions" in the novels of Graham Swift and Julian Barnes, David L. Higdon argues that they:

[W]ill undoubtedly be used for some time to explore and define British postmodernist fiction, especially in terms of their shared thematic and structural interests, and their creation of a new type of narrator, the reluctant narrator, who is reliable in strict terms, indeed often quite learned and perceptive, but who has seen, experienced or caused something so traumatic that he must approach the telling of it through indirections, masks and substitutions. (1991: 174)

Now apparently contemporary British novelists, among whom we may also count Kazuo Ishiguro, Ian McEwan, and Martin Amis, give way to the radical ambiguous nature of postmodern confession. It manifests itself in the wish to reveal oneself and in the drive to escape from the totality of disclosure, which leads to a shift in focus from the life of a narrator to the story of a hero. This idea will be elaborated in our paper on the material of The Pregnant Widow.

Another intriguing tendency was pointed out by Jo Jill in his introduction to the volume entitled Modern Confessional Writing: "[...] What is distinctive [...] is the flamboyant and persistent foregrounding of such knowledge [the nature and limitations of confessional writing] ... its double self-reflexivity; it is self-declaredly knowing about the knowingness of its model" (2006: 8). In other words, the narrator but knows how his words will be treated by his listener and gives his own deconstructive revision of its formulaic reading. The postmodern confessional narrator is often not only capable of philosophical meditations but prone to popular recent frames of Trauma / Identity / Culture studies, not to mention literary analytical vocabulary and intertext. We should agree with the idea that "[...] by combining the confessional with the metafictional the confessional is fatally compromised" (Jill 2006: 107). This profound skepticism about the language of consummation and truthfulness gives way to the idea of a constructed confes- 
sion that is opposed to an acute and painful life experience which cannot find its adequate verbal, genre and analytical frame within a postmodern confessional narrative.

\section{Traumatics}

Doorkey is a doornail, and the flap on the letterbox is a meat-slicer, and the very air is full of spikes and blades.

The Pregnant Widow (2010) by Martin Amis is an openly autobiographical, confessional and self-reflexive novel. If the classical confessional novel is distinguished by the preoccupation with suffering, Amis puts at the very center of his book the popular idea of trauma and provides an extended list of trauma definitions inspiring broad commentaries on its possible personal, social and artistic implications. It is enough to have a look at the composition of the chapters to find Amis's playful if not mocking use of the Freudian trauma approach. Significantly, Amis's narrator starts his Introduction to the novel with the following words: "This is a story of sexual trauma. He wasn't at a tender age when it happened to him. He was by any definition an adult; and he consented - he comprehensively consented. [...] It was the opposite of torture, yet it twisted. It ruined him for twenty-five years" (1). The novel provokes the analyses of Nachträglichkeit, Verspätung and Bahnung and introduces the chronological order which is subordinated to the order of (psycho)analytical frame. Amis pretends to be a self-made analyst, who is writing for and against futile quests for the autonomous self of his character: "According to the neo-Freudianism that was dominant in his era, these were the cornerstones of the self - sex, death, dreams, and human ordure, or night soil" (88). He voices a collection of explanations which clothe the story and characters in terms like superego and id, neurosis, depression, trauma, wound, ethical turn, etc. Amis wittily demonstrates his ability to give his own "reading the wound" in Geoffrey Hartman terms, by which the scholar means speculation on problematic and often ambivalent relationships of words and trauma (1995: 537).

An interest in the origins and effects of personal and interpersonal traumatic experience is not new for the author. Almost all his novels are centered on painful experiences. Some of them even produce an attempt to act out psychoanalytical scenarios: John Self's (id) battle with "Martin Amis"(super-ego) in Money (1985), the narcissist projection of a double in Success (1978), mid-life crises in The Information (1995), etc. A far more complex treatment awaits readers of The Pregnant Widow. The novel gives too many keys to permit its interpretation as a study of narcissism from psychological and cultural points of view, e.g. from the story about the Italian summer trauma of Keith, the hero, to the effects of the sexual revolution on a whole group of characters. Overt playfulness with the narcissistic element in the narrative composition of the text provides an example of the so-called "short circuit" (David Lodge) structure and highlights the same 
mirror theme of likeliness-difference between the author (Martin Amis), the narrator (the mature Keith, an author's mask) and the hero (the young Keith).

This provocative turn which pushes the reader to an easy interpretative scheme is perhaps connected with the biographical boom around Amis' family life and public discussions of his father's and his sister's ill-fated endings, as well as the posthumous publication of The Letters of Kingsley Amis (2001) and a book of memoirs Experience (2000) written by Martin Amis himself. Moreover it could be an indirect answer to a number of scholarly analyses. ${ }^{1}$ Finally, it might be animated by Nabokov's influence, his notorious feeling of amazement and doubt regarding Freudianism, playful use of psychoanalytical subtext and employing first-person narrators. Thus, in short, it could be a reaction to false coherence, wholeness and closure in the confessional text.

What is actually important in this playful trauma study by Amis is the link which trauma fiction shares with postmodern fiction - "a tendency to bring conventional narrative techniques to their limit" and to "question the very forms of meaning-making" (Whitehead 2004: 82). Classical Freudian perspective turns out to be too straightforward when laid bare in the self-reflexive frame of the novel. Rather, Amis's elaborate metafictional text incorporates those Freudian ideas used by Jacques Derrida: the idea of Aufeinanderschichtung and Erinnerungspuren - the psychic mechanism of permanent restructuring the order and value relations between different traces of personal memory, an act of rewriting - Umschrift.

There is no text written and present elsewhere which would then be subjected, without being changed in the process, to an operation and temporalization ... which would be external to it, floating on its surface. [...] The text is not thinkable in ordinary or modified form of presence. [...] Everything begins with reproduction. Always already: repositories of a meaning which were never present, whose signified presence is always reconstituted by deferment, nachträglich, belatedly, supplementary [...]. (1972: 92)

Derrida argues that trauma cannot reside in an event, which resists conceptualization, but finds itself in the effects of an event. The latter has taken place because of the rupturing and wounding within the subject.

[...] What Keith was left with [...] was a sudden memory of his sister [...] And then haphazardly came other memories. Like the time she ran the length of the garden and returned to him the lofted cricket ball, and then ran back again, and weeping throughout - weeping about something else. And then came other memories. Needing to be rescued. What was he to do with them all? In this new world he had entered (it was very developed, very far advanced), thinking and feeling were rearranged. And this, he thought and felt, might show him another way. (329-330)

Any meaning is always original and constructed nachträglich. Apart from its allusion to Herzen, the title of the book The Pregnant Widow is a symbol for this 
lack of origin. The "origin" is to be discovered in the narrator's efforts to write and rewrite the past. Even repetitive compulsions in his memories obtain different explanations. At the very beginning trauma is introduced as a personal sexual fall into narcissistic self-pleasure. Then comes a developed cultural analysis of the 1970s with "a new intensity of self-absorption" (59), the Golden Age of sexual revolution as an epoch which established a new codex of social and sexual behavior. "They were the Is, they were reflections, they were fireflies with their luminescent organs" (83). As the novel does not convey historical experience in its full weight, it is the narrator who explains its impact on the lives of characters. Even the date of Keith's birth - August $29^{\text {th }}, 1949$ - is already retrospectively indicative of collective trauma. It is the birthday of the Russian bomb and the starting point of the Cold War Period, a particular context to which Amis addresses earlier in his collection of short stories Einstein's Monsters (1987). But later in The Pregnant Widow traumatic event is closely associated with Violet, Keith's sister who is deceased by the time of the narrative. Thus, narrative, the lure of gathering, by which memories and feelings of what happened are newly restructured around the wound and the traces of origin, gets no possibility of referring to an ultimate form of confession. Finally, the narrator gives us the most repetitive idea of Amis' oeuvre: life as an experience per se is a traumatic event, it resists conceptualization and wounds.

\section{Lack of consummation}

Is this the time to clear up the question of who I am? Not just yet, I don't think. But I would like to put some distance $[\ldots]$.

In his book Experience Martin Amis writes that his life seems to him shapeless, that he knows well how to create plot and composition, unity of design in the fictional life of a character, but in real life there is an obvious lack of order. It is a meditation upon the loss of control, both in literature and in life, and an attempt to reassert control - to restrain chaos and contingency, the very things that energize Amis's novels. Later, talking about The Information, Amis makes an important remark, revealing a significant relation between author, narrator and character in his later novel: "[...] For me the mid-crisis came in the form of blanket ignorance [...] I felt that I had to open up to the reader about that and say 'How can I be an omniscient narrator when I don't know anything'" (Laurence). Thus, the novel is preoccupied with genre autogenesis against life's chaos and ignorance. The story of the Italian summer

aspired to at least partial coherence; it had some shape, some pattern, with its echelons [...] Once that was over, all he had was truth and chronology - and, oh yes, the inherently tragic shape (rise, crest, fall)[...] But it turns out that there's another way of doing things, another 
mode, another genre. And I hereby christen it Life. [...] Life has no time for the exalted proprieties, the ornate contrivances, and the intense stylizations of kitchen-sink [...] Life is made up as it goes along. It can never be rewritten. It can never be revised. (394)

But before Keith reaches this insight he "revisits" his life with some of the tools of a literary critic. The novel and the protagonist display a narcissistic preoccupation with their own genesis. "I can remember myself, I can to some extent perceive myself through my outer sense, and thus render myself in part an object of my desiring and feeling - that is, I can make myself an object for myself. But in this act of self-objectification I shall never coincide with myself," - writes Mikhail Bakhtin in his early essay Author and Hero in Aesthetic Activity (1990: 38). There is an unequivocal need for the Other to gather and unify all random activities of the self to produce an outwardly finished personality. The Other, then, is analogous to the author, who is "the living bearer and sustainer of the unity of consummation". The authorial "consummation" provides the sense of coherence which Paul Ricoeur calls "emplotment" or "configuration".

There is a particular way how Amis deliberately creates ontological confusion here. According to David Lodge, through such technique as short circuit, by which he means "combining in one work violently contrasting modes - the obviously fictive and the apparently factual; introducing the author and the question of authorship into the text; and exposing conventions in the act of using them" (1977: 240) postmodern fiction undermines interpretation. The main short-circuit intrigue of The Pregnant Widow is performed through a dialogue between the narrator (the author's mask) pretending to be omniscient about the hero and the hero of the novel - young Keith, a would be literary critic, who confesses to not knowing in what genre of the novel he finds himself a character. Both of them share some of the biographical experience of the real Martin Amis as a person and a literary man. This gives the novel extra self-reflexivity. One is inclined to see here a confessional autobiographical novel with a loophole: Amis writes about himself as if about the other, but he gets the right of the character's consummation while playing with the boundaries of one's own and his narrator's consciousness. Knowing and not knowing about the self-consummation is at stake in the novel.

What is considered consummation here? Literary genre canons. To know the genre one is in means to know one's self and one's fortune. This is exactly what the character strives to and what he wants to escape. "What genre did I visit, on my animal birthday? This was the question he couldn't answer. What mode, what kind? [...] Again and again he thought, What category am I in?" (2010: 322). This genre obsession echoes some novels by Amis, especially the first one The Rachel Papers (1973). At that point of his life Amis is already a literary critic at The Times Literary Supplement. And his professional preoccupation with genre turns to be curiously connected with personal and artistic selfdetermination. A postmodern confession of his first novel's protagonist Charles Highway puts together a male coming of age story, literary fashioning of the first "traumatic" love episode, and Oxford entrance essay entitled "Experience". 
Such revisiting of the first novel's scheme is an important self-reflexive key which establishes a kind of "initiation plot" for Keith. On the eve of his "animal birthday" he writes his first review on the monograph Antinominalism in D.H. Lawrence. In a brilliant ironic twist traumatic sexual intercourse with Gloria is engaged in Keith's awareness of his inability to be a romantic poet. In this respect his interest in genre conventions is not coincidental. Upon his arrival at the castle Keith feels ready to have new sexual experience, combined with a necessity to fill in the gaps in his knowledge of English novel tradition from Fielding, Richardson and Austen to Bronte, Dickens, Eliot and, finally, Lawrence. He consistently turns to the genre canon in order to redefine options for love plot development. The erotic fever inspired by inaccessible Sheherazade is infused into Keith's critical interpretation of the classics. It drives Keith's quest to find a particular equation, implying that the novelistic text may offer not merely a love plot, but a special kind of sexual performance written according to some genre conventions. ${ }^{3}$ Amused by his reading of Richardson, Fielding and Austen, Keith is especially sensitive to the novel's self-reflexivity and estrangement of conventions. For him it is clear that Catherine Moreland, the character of Jane Austen's Northanger Abbey, who perceives everything around her to be out of a Gothic novel, is dull-witted because she cannot find her place in the fictive reality of other genre conventions. "But when a young lady is to be a heroine [...] Something must and will happen to throw a hero in her way" (5). That is why Keith is eager to know his fortune, his own true consummation as if in narrative.

The hero attempts to define the most appropriate genre for his love plot and restore a specific history of novel writing conventions. According to Keith, the classic English novel explores a question: "What were heroines allowed to do?" (154) But what were heroines allowed to do in the novel dated 1970 with a protagonist named Keith? Mostly the comical libidinal reflections of Keith are interrupted by an extraordinarily mature insight:

\footnotetext{
We come to item four in the revolutionary manifesto, and, yes, this was the one that caused most of the grief [...]. In the seventeenth century, it is said, there was a dissociation of sensibility. The poets could no longer think and feel at the same time. [...] Something analogous happened while the children of the Golden Age were becoming men and women. Feeling was already separated from thought. And then feeling was separated from sex. So the position of feeling found itself (again) shifted. This was one that almost did for him, and for the scores of thousands - perhaps tens of millions - of others. (2010:309)
}

It is pornographic performance that becomes a new genre for Keith's generation. Amis has been researching pornographic culture since the 1970s. First, as an author of Dead Babies, then as a New Statesman columnist displaying "his determination to unflinchingly document the devaluation of love and eroticism in the postmodern West". The imagery and performances of self-confessed pornography addicts in Amis's Money, London Fields (1989) and The Information are designed to translate the hero's new sensibility. Here Amis replays once again his 
favorite idea of genre and hero decadence with the reference to Northrop Frye's Anatomy of Criticism (1957). Already in The Information the unsuccessful selfreflexive writer Richard Tull likes Steve Cousins, a criminal obsessed with pornography. Interesting in its own right, Tull's view contains critical observations that transcend genre consideration:

He had liked Steve Cousins because he was the hero of a novel from the future. In literature as in life everything would go on getting less and less innocent. The rapists of the eighteenth century were the romantic leads of the nineteenth; the anarchic Lucifers of the nineteenth were the existential Lancelots of the twentieth. And so it went on, until [...] Cousins: free spirit and scourge of hubris. (1995: 464)

Similarly, in The Pregnant Widow, Keith's life assumes all the characteristics of an almost uncontrolled fall into the psychology of "the pornographic imagination" (Susan Sontag). The son of 'the pregnant widow', which Amis initially envisions as a messenger of sexual revolution, Keith could easily find himself within a pornographic novel. The delineation between real experience and love simulation is so blurred that Keith is uncertain:

Again and again he thought: What category am I in? In its lustres and static facets it often reminded him of the pages of a glossy magazine - fashion, glamour. But what was its type as drama, as narrative? He was sure it wasn't romance. [...] It might be science fiction. Or advertising. Or propaganda... It seemed to make sense only when you watched it in the mirror. (322-323)

The sexual power of an image in a mirror could refer to examples such as The Image (1956) or Story of O (1954, screened in 1974-1975). Mirrors turn us into Narcissus, reflected in glittering surfaces of pornography. Ironically, from the very start of his stay in the Italian castle, Keith desires to find a (literary) critical metaposition. He is ready "for change, for category mistakes and shape-shifting and bodies becoming different bodies [...]" (149) and defines his sexual experience in terms of a genre "that belonged to the future" (317). But again Amis's strategy of metadiscourse develops a remarkable ambiguity towards Keith and his yet unknown genre consummation. It is the narrator (mature Keith), or even the author himself, who is "transgressive" to the hero and therefore is able to "collect the hero and his life and to complete him to the point where he forms a whole" (Bakhtin 1990: 38).

However, the fact that The Pregnant Widow imitates a pornographic novel as a means to obtain a complete perception of Keith's experience does not lead us to a conclusion that it in fact becomes a pornographic novel. Amis' self-reflexive narrative as a whole lets us know how it should be read and how far we should trust the author's attempts to direct us towards a certain reading. Akin to Lolita by Nabokov, which is often claimed to be one of Amis' favorite novels, The 
Pregnant Widow is only a pastiche of "a sex novel about sex" (Anderson 2010). Rather, it is a "confession with a loophole".

\section{Confession with a loophole}

For Bakhtin, the self "ever coincides with itself" because it is always in the process of becoming as the final word has not yet been spoken. The Underground Man speaks "the word with a loophole" which "is the retention for oneself of the possibility for altering the ultimate, final meaning of one's own words" (1984: 233). This dialogic dynamic - "confession with the loophole" - perpetuates a cognitive liminality which makes the subject's sense of identity so precarious. Thus, the confessional process simultaneously appears to reject and rely on the narrativizing consummate perspective of the transgressive Other.

Though The Pregnant Widow does not appear to be a self-enclosed solipsistic text, it unmistakably questions story-telling as an existential necessity. Neverunified and un-consummated, the confessional self evolves not from life-writing but from life-reading. Alfred Hornung in his research paper Reading One/Self argues that:

[The] act of refiguring a story from the fragments of one's art and life seems to be expressive of the latent wish of reading the unity of one self. It is the very discourse of earlier writings which foregrounds auto-referentiality of a deconstructed subject in the postmodern world. Reading and writing as human activities in search of control [...] would then correspond with Gabriel Schwab's interpretation of Bakhtin's dialogic imagination in the dual role of stabilization and subversion. (1987: 184)

This function of the dialogic imagination is at the root of contemporary oeuvre discussed by Hornung: Samuel Beckett, Thomas Bernhard, Peter Handke, John Barth, Alain Robbe-Grillet. Amis, at that time the author of Money, is only mentioned briefly. Today he should be considered a permanent resident on this list. Not only does he build himself from the rags of his early novels, he does so in dialogue with the Other - his younger narrative self. Amis's extensive use of selfcitation, his recognizable leitmotif clusters and his self-reflexive genre study are signs of his confession with the loophole when put in perspective against his own earlier novels. Amis seeks to display traces of his maturing as a person and as an artist in the deceptive mirror of narrative. And the very possibilities of differance are more important than a self-inscription project. Thus, when Amis uses a wellworn dream scenario in The Pregnant Widow, it appears to be a rereading of some key leitmotifs of his earlier writing 
The drug gave him (Keith) continuous sleep - and continuous dreams. And after a night spent losing his passport and failing to rescue Violet and missing trains and nearly going to bed with Ashraf [...] and sitting exams in the nude (with an empty fountain pen), Keith awoke to criticism [...]. (269)

A leitmotif of "losing passport" serves for the idea of mortality and identity crisis throughout Amis's oeuvre; "failing to rescue the sister" - a repetitive existential situation in his novels, supported by the Amis family history; "trains" - is a usual sign of bad fortune; and "sitting exams" while feeling doubts about one's literary gifts (empty fountain pen) - is an initiation plot in several novels of the author, including his debut The Rachel Papers.

No narrative integration of self can be achieved although the saddest of truths about the elusive quality of self may in fact be captured through leitmotifs emphatically pointing to the wound metaphors, the signs of untold suffering, and the character's wish to escape painful acknowledgement of guilt, shame and decline. Among the most repetitive motifs of Amis are loss of innocence, human disintegration, physical decay, degradation and pain. All of them constantly reappear throughout the writer's career and have much wider reference than, for example, sexual revolution. From the first novel The Rachel Papers onwards, Amis continues to be motivated by the vulnerable experience of decay and inevitable death.

The ambiguity regarding The Pregnant Widow is created by the fact that the novel as a whole is neither unremittingly metafictional nor entirely "straight". "Everything that follows is true [...] Not even the names have been changed. Why bother? To protect the innocent? They were not innocent. Or else all of them were innocent - but cannot be protected" (4). Does Amis mean nobody can be protected from death? We are confronted with unsettling effects when both the Italian story of libido exhibitionism and historiography surveys are debunked. "All for a - all for a session [...] There's something else. There's this other thing. I don't know what it is. It can't be to do with Violet, can it? How can it be?" (228). The answer is given later: "Narcissus's sister. [...] The older story was the one that hurt and connected" (390).

There are two "haunting whispers" in the novel which are not tightly connected with the Italian summer. One is a theme of a lost sister and orphanhood. The other is a profound awareness of one's physical decay. This recontextualizes the novel from mere comic observations on sexual mores to a truly confessional framework for Keith's life. Faced with his condition in a self-reflexive mirror, the hero aspires to reconcile outwardly expressed horror and despair and deep internalized suffering. Both themes epitomize the philosophy of loss and reinterpret the Narcissus emblem.

Amis continues to master playful literary intertext, the hallmark of his style. But now there is nothing like literary fashioning of life. Rather, his deeply moving account of life is perceived as inevitable failure. Yet through the lens of literary allusions the "trauma was a secret you kept from yourself" (390). An artifice erects a defense mechanism which enables the author(s) to approach emotional 
challenges and painful experiences through indirections, masks and substitutions.

For example, the novel was written partly to account for the early death of Amis's sister Sally. Her name in the novel was changed to Violet. It might be connected with the version of the myth of Narcissus, which Keith read in Italy: "Narcissus had a twin sister, an identica, who died very young. When he leaned over the untainted pool it was Narcissa whom he saw in the water. And it was thirst, and not self-love, that killed the glassy boy; he wouldn't drink, he wouldn't disturb that rapt reflection [...]" (386-387). Deep mourning here is a sign of selfloss which is orchestrated in naming Keith's sister Violet, a name of the flower, a kind of a correlate to Narcissus. "And with Violet alone he suffered no disadvantage, no displacement [...]. It was love from the first sight" (463). Now the ideal of wholeness or completion is lost forever. "It's the deaths of others that kill you in the end" (464).

Moreover it might allude to Shakespeare's Twelfth Night Viola and her lost twin brother Sebastian. Viola, Violet, Pansy are the flowers of the same violet family. Girls with "flower" names enter Keith's life to bring innocence, faithfulness and fidelity grossly betrayed by life. Keith's deep sorrow and grief about them is also comparable to those of Ophelia passing by pansies and violets with their loaded symbolism in the famous Hamlet scene. On the other hand, the image of betrayed Ophelia echoes Arthur Rimbaud's Ophelia, which "floats like a great lily". A girl named Lily is the first romantic love of Keith.

Further, it might not be coincidental that the narrator chooses the late poems in D.H. Lawrence's oeuvre titled Pansies (1929) as those "opposite of narcissism, the end of narcissism - the human closing of it" (157). The title of the collection refers to Ophelia's replica "pansies, that's for thoughts" (the English word derives from the French pensées). But Lawrence himself adds that "if you will, have the other derivation of pansy, from panser, to dress or sooth a wound [...]" (Rawson, 2011: 487).Written in 1929 shortly before the death of the poet, Pansies also brought to mind the well-known Bavarian Gentians, one of the great poems about a mystic embrace of death. Besides, Lawrence's biography is inscribed within the novel as well as his life and philosophical "antinomies" of sex and death (note the title of the book first reviewed by Keith). All of this helps to perceive an elusive confession about life as 'a tragedy, sometimes sooner, always later" (2). "Death - the dark backing a mirror needs before it can show us ourselves. It isn't vanity, it was never vanity. It was always death. This was the true and universal metamorphosis: the agonizing transfiguration from one state to another - from the state of life to the state of death" (462).

A set of coherent assumptions about Amis's oeuvre as an artistic whole may be revealed within this constellation of relationships. But do they point a way to interpret his confessional self? Sets of repetitive textual clusters are not redemption from chaos and dynamism of self; neither do they bring consolation as reward for this eventual truth-seeking. Rather, their persistence brings into light the author's poignant themes of loss, vulnerability and fragile human experience not on a glossy surface of the mirror but in the ebb and flow of never ending 
confessional writing of the self. "Find a mirror you like and trust, and stick to it. Correction. Find a mirror you like. Never mind about trust. Stand by this mirror, and be true to it. Never so much as glance at another [...] All the mirror gives you $[\ldots]$ is a rough idea" (111).

\section{Notes}

$1 \quad$ For an example of such scholarship see Valentina Adami, Martin Amis's Time Arrow as Trauma Fiction (2008), where the breakdown of chronology, coherence, and predictability mimics the collapse of temporality and the crisis of truth caused by trauma in the individual mind.

2 For a fuller discussion of this see Daphna Erdinast-Vulcan's articles "The I that Tells itself: A Bakhtinian Perspective on Narrative Identity" (2008) and "Borderlines and Contraband: Bakhtin and the Question of the Subject" (1997), as well as Barbara Z. Thaden's "Bakhtin, Dostoevsky, and the Status of the 'I'" (1987).

3 Henry Tilney, a character in Northanger Abbey, articulates a reflexive attitude towards genre in the twentieth chapter of the novel, which parodies Gothic novel conventions. It is worth noting that in his first twenty reviews written for The Observer in the period from 1972 till 1974, the young Amis signed with the penname "Henry Tilney".

\section{References}

Amis, Martin (1995) The Information. London: Flamingo.

Amis, Martin (2011) The Pregnant Widow. London: Vintage Books.

Adami, Valentina (2008) Martin Amis's Time Arrow as Trauma Fiction. Frankfurt: Peter Lang.

Anderson, Sam (2010) The return of Martin Amis. New York Magazine, 7 May, Web. http://www. nymag.com/arts/books/reviews/65889 (Accessed on 2 May 2017).

Austen, Jane (1994) Northanger Abbey. New York: Penguin books.

Axthelm, Peter (1967) The Modern Confessional Novel. New Haven and London: Yale University Press.

Bakhtin, Mikhail (1984) Problems of Dostoevsky's poetics, Trans. Caryl Emerson. Minneapolis: University of Minnesota Press.

Bakhtin, Mikhail (1990) Author and hero in aesthetic activity. In: Art and Answerability: Early Philosophical Essays by M.M. Bakhtin. Trans. Vadim Liapunov. Austin: Texas University Press, 4-256.

Derrida, Jacques and Jeffrey Mehlman (1972) Freud and the scene of writing. Yale French Studies 48, 74-117.

Diedrick, James (2004) Understanding Martin Amis. South Carolina: University of South Carolina Press.

Erdinast-Vulcan, Daphna (2008) The I that tells itself: A Bakhtinian perspective on narrative identity. Narrative 16 (1), 1-15.

Erdinast-Vulcan, Daphna (1997) Borderlines and contraband: Bakhtin and the question of the subject. Poetics Today 18 (2), 251-269.

Gill, Jo (2006) Introduction. In: Gill, Jo (ed.) Modern Confessional Writing. London and New York: Routledge, $1-10$.

Higdon, David (1991) Unconfessed confessions: the narrators of Graham Swift and Julian Barnes. In: Acheson, James (ed.) The British and Irish Novel Since 1960. New York: St. Martin's Press, 174-191. 
Hornung, Alfred (1987) Reading one/self: Samuel Beckett, Thomas Bernhard, Peter Handke, John Barth, Alain Robbe-Grillet. In: Calinesku Matei and Douwe Fokkema (eds.) Exploring Postmodernism. Amsterdam and Philadelphia: John Benjamins Publishing Company, 175-198.

Hartman, Geoffrey H. (1995) On traumatic knowledge and literary studies. New Literary History 26, 537-563.

Laurence, Alexander and Kathleen McGee. No More Illusions. The Write Stuff [Interviews] Web. http://www.altx.com/int2/martin.amis.html (Accessed on 2 May 2017).

Lodge, David (1977) The Modes of Modern Writing: Metaphor, Metonymy, and the Typology of Modern Literature. Cornell University Press.

Nicol, Bran (2006) Dave Eggers and the memoir as self-destruction. In: Gill, Jo (ed.) Modern Confessional Writing. London and New York: Routledge, 100-114.

Rawson, Claude (2011) The Cambridge Companion to English Poets. Cambridge: Cambridge University Press.

Thaden, Barbara Z. (1987) Bakhtin, Dostoevsky, and the status of the 'I'. Dostoevsky Studies 8, 200-207.

Whitehead, Anne (2004) Trauma Fiction. Edinburgh: Edinburgh University Press.

Olga A. Dzhumaylo, Prof. Dr., Associate Professor of English literature at Southern Federal University (Russia). Her monograph The English Confessional Novel. 1980-2000 (2011) explores interrelated questions of the confessional turn, a re-evaluation of the postmodern subject, and the poetics of self-reflexivity in the novels of Kazuo Ishiguro, Ian McEwan, Graham Swift, Julian Barnes and Martin Amis. She is the Editor-in-Chief of 'Practices and Interpretations: a Journal of Philology, Teaching and Cultural studies'.

Address: Olga A. Dzhumaylo, 93, Universitetsky Str., office 8, Rostov-on-Don 344006, Russia. [email: o.dzhumaylo@gmail.com] 
